\title{
Gender Labor Policies in the Franco Dictatorship (1939-75): The Discursive Construction of Normative Femininity
}

\author{
Uxía Otero-González
}

University of Santiago de Compostela

\begin{abstract}
This article analyzes the labor gender policies and the strategies of "genderization" put forward by the Franco Dictatorship in Spain. The Franco regime understood that women were the touchstone of society and key in both biological and sociocultural reproduction. Legislative regulations and sanctioned discourses accentuated the division between productive-public and reproductive-domestic spheres, relegating women to the latter. Nevertheless, to what extent did women embrace and challenge the regime's idealistic view of gender? This article contemplates female employment within and beyond official discourse. Oral sources used in this article suggest that socioeconomic reality overflowed the narrow limits of normative femininity. Not all women could enjoy the "honor" of embodying the exalted role of "perfect (house) wife" that the Franco regime had entrusted to them. In addition, this article explores changes in the ideal of femininity throughout the dictatorship. The Franco regime underwent crucial transformations during its almost 40 years of existence. This article argues that its adaptation had repercussions on sociocultural patterns and gender policies. Francoism built its early notion of normative femininity on the ideals of domesticity and Catholic morality, but (re)shaped the meanings of womanhood and (re)adjusted the legal system to fit the new circumstances that arose in the Cold War context.
\end{abstract}

\section{Keywords}

Gender; Femininity; Labor Policies; Franco Dictatorship

\section{Introduction}

"Now that the custom of girls studying and working in offices is becoming more widespread than ever, keep in mind that [...] the woman's main

\footnotetext{
* Uxía Otero-González Department of History - Contemporary History, Faculty of Geography and History, University of Santiago de Compostela, Spain; uxia.otero@usc.es; https://orcid.org/00000002-7839-9870.
} 
mission is at home." ${ }^{1}$ For almost 40 years (1939-75), Spanish women were constantly exposed to statements such as this at school, in the workplace, and especially, in their homes. This article analyzes the labor gender policies and the strategies of "genderization" put forward by the Franco Dictatorship. This article focuses on the discursive construction of normative femininity throughout the dictatorship, drawing on work-related laws and characterbuilding literature--such as school manuals, doctrinal texts of the Catholic Church, and magazines of the feminine branch of the only legal political party (FET-JONS).

This article discusses female employment within and beyond official discourse. In addition to the prescriptive discourses of a legal, political, educative, and religious order, oral sources help us to gauge to what extent women embodied the official domesticity discourse. The life stories method (Llona 2012) allows us to explore the identity construction of "being a woman" through memory, a field of action in which "perceptions of being" are continually negotiated. In this sense, oral history is not so much to evidence, contrast or refute historiographical premises, nor complement the information provided by traditional-written sources, but rather to understand the meaning of these. Oral testimonies help us understand that official gender discourses and policies do not have to be interpreted as self-evident or confused with what happened in practice, that is, with the way in which that ideal was reproduced, assumed, adapted or contested by women. The interviews analyzed here come from two collections. The first collection is composed of interviews conducted expressly for this ongoing investigation, and therefore they were semi-structured based on the concerns of this research. Likewise, interviews of pre-existing oral collections also provide us valuable information when being interpreted from a gender perspective. This is the case of the HISTORGA Collection of Terra e Memoria, an archive of oral sources organized from the funds of the Contemporary Documentary and Oral Heritage Unit (UPDOC) and which compiles an ongoing oral fundraising activity that began in the late 1980s in the Department of History of the University of Santiago de Compostela. ${ }^{2}$

Finally, this article explores changes in the ideal of femininity throughout the dictatorship. The Franco regime underwent crucial transformations during its almost 40 years of existence. This article argues that its adaptation had repercussions on sociocultural patterns and gender policies. Francoism

1 Sección Femenina de FET-JONS, "Curso séptimo. Lección octava. Influencia de la mujer en el hogar. El ama de casa. Rehabilitación de los quehaceres domésticos," [Course seven. Lesson eight. Influence of women in the home. The housewife. Rehabilitation of household chores.] In Formación familiar y social (Madrid: Delegación Nacional Sección Femenina de FET-JONS, 1969), 228.

2 “Terra e Memoria." 2018. https://www.terraememoria.usc.gal/ 
built its early notion of normative femininity on the ideals of domesticity and Catholic morality but (re)shaped the meanings of womanhood and (re) adjusted the legal system to fit the new circumstances that arose in the Cold War context. Gender order began to crack from the 1950s when women increasingly pursued secondary and higher education as well as professional careers and jobs related to a growing service economy. A turning point in the official gender model became more evident in the 1960s. This is linked to substantial political, economic, and sociocultural (re)adjustments adopted by the regime.

This article has been developed within the framework of an ongoing dissertation that explores the normative femininity of the Franco dictatorship and its sartorial embodiment. This research draws on the extensive existing historiography on Francoism and incorporates "gender" as a category of historical analysis, following Aurora Morcillo's historiographical proposal (2000, 2010, and 2015).

\section{“Returning Home" by Law}

Military forces that staged a coup d'etat against the legitimate government of the Second Republic (1931-36) began to erect barriers to limit and discourage female employment before even being the victors of the civil war (1936-39). The first provision in this respect was established in the 1938 Labor Charter, which had certain similarities with the fascist Carta del Lavoro: "The State [...] shall free married women from the workshop and the factory." Some media sympathetic to the regime, and which was to become one of the main forms of transmission of the official discourse of femininity, widely reported and praised this regulation. The pages of $Y$ - a magazine published by the FETJONS Feminine Section - talked about it as "a pro-family policy." In other words, Franco's labor policy oscillated between prohibition and protection, closely linked to pronatalist demographic policies. The "liberation" was even more clearly formulated in the Order on Women's Work of December 27, 1938: "The trend in the New State is for women to devote their time to the home and stay away from employment." Likewise, the "Mitigating Measures" prohibited "the employment of a married woman on the basis of a certain level of income received by her husband" (Art. 4). 5

The "New State" had no intention of protecting those women who, without obligations, registered in search of economic independence. The Ministerial

3 Official State Journal 505 (March 10, 1938): 6178-81.

4 Juan Bosch Marín, "El Fuero del Trabajo y la mujer" [Labor Law and Women], Y3 (1938): 20.

5 Official State Journal 183 (December 31, 1938): 3219-20.

198 
Order dated November 17, 1939, prohibited women from registering at employment offices and labor exchanges; except in the case of heads of households with no other incomes, if their husbands were unable to earn income for the home or if they were single, either without means of subsistence or in possession of qualification for professional practice. ${ }^{6}$ The employment offices and labor exchanges should automatically unsubscribe all those female registrations that did not meet the indicated conditions. In addition, companies or employers had to go to such placement agencies to fill vacant jobs. Inspection bodies may agree to terminate employment relationships that did not comply with this obligation (Espuny 2007a).

Furthermore to regulations forbidding or limiting women's work, "protective measures" were introduced to discourage female employment, or rather, to encourage them to give up their jobs in relation to demographic policy. ${ }^{7}$ For example, the Decree dated February 22, 1941, which improved the system of family subsidies implemented in $1938 ;^{8}$ or the Order dated March 29, 1946, ${ }^{9}$ which deprived men whose wives worked outside the home of their family allowance implemented in $1945 . .^{10}$

Many labor ordinances and work regulations - elaborated according to the Law of October 12, $1942-{ }^{11}$ established that when contracting marriage, the female worker would have to leave her job (Ruiz 2003, 126). During the 1940 s and 1950s, under the jurisdiction of the 1938 Labor Charter, both public and private companies included specific clauses of "forced leave" in the case of marriage. Based on this "contractual celibacy," sometimes with the right to re-entry in the event of widowhood or incapacity of the husband for work (Espuny 2007b). The displacement of married women from jobs often occurred in exchange for previously stipulated financial compensation known as "dowry," although this name has been widely disputed by case law. This compensation could be equivalent to the amount of as many monthly payments as years of service or be limited to a maximum of monthly payments, but not all the regulations contemplated such compensation (Gómez 1970).

6 Official State Journal 323 (November 19, 1939): 6507-8.

7 Protective measures like these have also been adopted since the early 20th century in other regimes as was the case with Mussolini's Italy and Primo de Rivera's Spain (Valiente 1997, 59-98).

8 Official State Journal 19 (July 19, 1938): 272-5.

9 Official State Journal 181 (June 30, 1945): 5401-2.

10 Resolution that interprets section c) of article eight of the Order of March 29, 1946 regarding family benefit. Official State Journal 100 (April 10, 1954): 2298-9.

This aid bore certain similarities to those promoted between 1933 and 1937 by the Nazi regime, which claimed to convince "women and girls to marry, thus taking them out of factories to put men in their place" (Escribano 2009, 202).

11 Official State Journal 296 (October 23, 1942): 8462-5. 
However, some regulations did not even include any clause in this regard, and others contemplated a leave of absence voluntarily. For example, article 121 of the Statute of the Primary Magisterium - approved by Decree of October 24, 1947 and modified by Decree of August 11, 1953- ${ }^{12}$ provided the possibility for married teachers to avail themselves of a "special voluntary leave." This was the case of Hilda, a teacher who asked for voluntary leave when she married:

I got married and took unpaid leave. Unpaid leave was one of Franco's measures for us to stay at home and be mothers. If I stayed at home, my husband got extra points and they increased his pay. It was called the family allowance. It suited him. And our first three children came along, followed by another two [...] Nobody wanted me to work. They used to say to me: 'If you go to work you'll end up earning less!' For them it was a source of shame. I would set the alarm to wake up just before him, and I would cry and say: 'Everything my aunt went through, and everything I went through to study, and now nothing.... In the end he said to me: 'What a burden! Okay, you should go back to work'. ${ }^{13}$

Being a teacher was important to Hilda. When she was 5 years old, in September 1936, the rebels troops murdered her parents, Balbina Gayo and Ceferino Farfante, principal and teacher at the Cangas de Narcea school (Asturias) (Iglesias 2007, 69-128). Since then, Hilda and her two sisters have never lived together again. Each stayed with different relatives. Hilda stayed with Guillermina, her mother's sister and also a teacher, and she feels very lucky to have been in her care.

What my aunt wanted for me was to become a teacher at any price. In my mother's family they were very poor, and they faced with many difficulties to study [...]. I wanted to go to the high school that was going to open just when I had [the appropriate age] to start. We're talking about the year 1941. I wanted to go badly, but it cost fifteen pesetas a month. What was not little in that time! [...] So I didn't dare tell her that I wanted to go there.

[...] The City Hall published in the bulletin board that they wew offering two scholarships for boys. I spent two or three days thinking. In the end I armed myself with courage and went there. [...] I went upstairs and knocked on the door... Knock, knock, knock! I asked: 'Mr. Jesús?' 'Come in', the mayor said. He looked at me thinking, and what does she want? And I say to him: 'Why are there no scholarships

12 Official State Journal 17 (January 17, 1948): 226-43; and Official State Journal 250 (September 7, 1953): 5388-9.

13 Hilda Farfante (Boal, 1931). Interviewed by Uxía Otero-González, in O Vicedo, on August 31, 2018; Author's Oral Testimonies Collection, no. 10. 
for girls?' It was just as I tell you. He picked up the fountain pen, went to the announcement, and wrote: 'Scholarships for two boys and one girl'. And he said: 'Come on, get out of here'. That scholarship had to be for me. So it was.

Hilda's tenacity was clear early on and persisted throughout her entire career. Despite the paternal absences, the economic difficulties her family suffered during the postwar and the new regime's purging process of Guillermina - she was suspended from employment and salary for a year-, as well as from the "slab of guilt" and the social stigma for being the daughter of "rojos" -a pejorative name referring to people loyal to the Second Republic and progressive ideas-, Hilda passed the public examination to become a teacher in 1953. After Guillermina's efforts and such a long road, Hilda was not ready to give up a career that was also her true vocation and part of her identity. Hilda never stopped practicing or working. While providing care for her children, she gave "some private lessons at home." After a few years of voluntary leave, she wanted to return to her position with her husband's approval. At this time, if a wife persisted in her desire to work, she had to have express marital authorization. The Employment Contracts Act of 1944 established as mandatory a marital authorization to sign an employment contract (Art. 11). ${ }^{14}$ Furthermore, this act opened up the possibility for the husband to object to his wife receiving her own salary (Art. 58) (Espuny 2008). The subordinate position of women, conditioned by male decision-making in the work sphere and in society in general, became even more apparent.

The Franco regime drew up a range of measures to discourage women from accessing and remaining in any job outside of the home. The conceptions and idea(ls) of the elites, and of those who were authorized to create discourse and opinion, explain these measures. Paying attention to the discursive constructions of gender ideals, the preponderance of economic arguments is questioned. As the sociologist Celia Valiente (1996) proposed, favorable or adverse sign of the economic conjuncture is not the best element to interpret the nature of the provisions regarding the female extra-domestic activity. At a good economic time, it would be reasonable to think that existing legislative barriers to women's work would relax. On the contrary, during an economic recession, protective measures would weaken, and obstacles would tighten. Despite the plausibility of such arguments, and without denying the influence

14 Decree of January 26, 1944, which approves the consolidated text of Book I of Employment Contract Law. Official State Journal 55 (February 24, 1944): 1627-34. The marital license was also required for many other matters, for example, to open a bank account, to apply for a passport, to sign a public deed, for a woman to have her own property, etc. This license was not revoked until approval of Act 14/1975, of May 2. Official State Journal 197 (May 5, 1975): 9413-9. 
of economic factors on the political decision-making process, during Franco's time, the protective measures and disincentive and limiting provisions on women's work took place both in adverse economic situations and in prosperity. Thus, it is not possible to find a clear link between the economic situation and the official discourses that discouraged and hindered women's extra-domestic work.

The legal mechanisms to discourage women's participation in the labor market were indirectly reinforced through the education system, thanks to a different socialization process for women. Labor legislation was the most direct mechanism of state intervention in the organization and segmentation of the labor market, but education was one of the most effective instruments in building the division between the productive and reproductive spheres. One of the first educational measures of the rebels was to suppress coeducation in September 1936. Given the connivance between the Francoist state and the Catholic Church, Francoist femininity was, to a large extent, inspired by Catholic ideals, and its policies were designed according to Catholic morality. The encyclical Divini Illius Magistri of Pius XI — the highest representative of the Catholic ecclesiastical hierarchy at the time- said this was a method "founded upon naturalism and the denial of original sin" and a "deplorable confusion of ideas that mistakes a leveling of promiscuity and equality" (Art. 52). ${ }^{15}$ In these years, Catholic discourse was based on difference and complementarity between men and women.

But gender segregation was both institutional and curricular. The Primary Education Act of 1945 established that "primary education for girls shall prepare especially for home life, handicrafts and the domestic industries" (Art. 11). ${ }^{16}$ The motto of the inspector and pedagogical instructor Agustín Serrano de Haro was: "No scientific knowledge for these girls. Their lab will be the kitchen; yes, the kitchen!" ${ }^{77}$ Women's education transcended the intellectualformative concept for the sake of comprehensive modeling. Girls were the target of a whole battery of instructions to teach them how to "be women," determine their aesthetics, define their life space and aspirations. Textbooks were specifically designed for girls:

There are many women who aspire to be independent and work outside the home. Why doesn't a woman aspire to the same independence with the work she does in the home? The woman must be like the industrial

15 Pío XI, Pope. "Divini Illius Magistri, On Christian Education." In Encyclicals. Vatican City: Holy See, 1929.

16 Official State Journal 199 (July 18, 1944), 385-416.

17 Agustín Serrano de Haro, La escuela rural [The rural school] (Madrid: Escuela Española, 1946), 128. 
partner of the husband and watch out for his interests, since he made her the depository of his confidence, bearing in mind that she, with his administration, is the main basis of the savings that will ensure the future welfare of the family. ${ }^{18}$

The official femininity that was (re)produced and transmitted at school was based on an ideal of domesticity that has been associated with the $19^{\text {th }}$ century "angel of the home." In the mid- $19^{\text {th }}$ century, the female activity rate stood at levels never seen before. The figure of the working woman became increasingly visible, playing a fundamental role in the economic survival of the family. Working women began to be perceived as problematic then. As the behavior of working-class women did not correspond to the angelic archetype, there was a legislative impulse in the first third of the $20^{\text {th }}$ century that advanced the discourse of domesticity. This discourse was based on the figures or models of the breadwinner - the responsibility for earning income for the family was from the men - and the housewife - the responsibility of reproduction and of good administration of the male salary fell on women - (Arbaiza 2000). The angelic archetype became institutionalized and popularized in the first decades of the $20^{\text {th }}$ century, but it was destined to reinvent itself and share space with new icons.

A timeless use of the "angel of the home" is problematic. The Francoist normative femininity is usually mechanically assimilated to this archetype without contextualizing and referring to the changes in the social imaginary, ignoring all reference to the liberal political framework that gave it life and petrifying this ideal in fixed, interchangeable and dangerously essentialist formulas. As the historian M.a Gloria Espigado (2018) pointed out, many historiographical publications reproduce ahistorical and stereotypically abusive clichés of the angelic archetype without major nuances. Despite powerful inheritances and points in common, Franco's regime did not handle this concept and the first third of the $20^{\text {th }}$ century was not in vain. The Francoist gender model did not constitute a simple return to the $19^{\text {th }}$ century and its angelic model, but it was not an ex novo creation either. According to the historian Aurora Morcillo (2000 and 2010), the Francoist model of femininity has its roots in a still earlier era. Morcillo considers that the Baroque and Francoism are politically and religiously close positions. The Franco regime reinvented and deployed Catholic values launched during the $16^{\text {th }}$-century Counter-Reformation. This is what leads to perceiving a neo-

18 Sección Femenina de FET-JONS, Ciencia doméstica [Domestic science] (Madrid: Ediciones de Auxilio Social, 1950), 112. 
baroque quality in the nature of the dictatorship and its "being a woman" (2015).

\section{Women's Work Beyond the Rules}

These gender conceptions and the existence of strongly restrictive policies invite us to believe that few women "defied" the norm and went out to work. Official statistics on female labor activity corroborate this hypothesis. According to the population censuses of the National Institute of Statistics, less than $10 \%$ of women of working age were employed in 1940 (Sarasúa and Molinero 2009, 322). However, does this percentage reflect the true volume of female workers? The crossing of legal and statistical sources with oral and photographical ones lead us to think that some of the diversity of cases and the multiactivity strategies that characterize life trajectories and experiences were made invisible. Therefore, the apparent overwhelming success of the official discourse must be interrogated.

Female employment tended to decrease in the first half of the $20^{\text {th }}$ century. Following the approach of the historian Mercedes Arbaiza (2000), the assignment of socio-professional categories in the population censuses and registers began to be based on the figures of the "breadwinner" and the "housewife," although, in practice, there was no such clear separation of functions and spaces. Different factors influenced this reordering and homogenizing classification, such as the social revaluation of the figure of the housewife. The activities related to the domestic space began to endow with economic value, namely "home economics." This revaluation could influence some women when they self-identify as housewives. However, when we asked about their occupation in these decades, women sometimes replied that they did not work. As the interview progresses, it is easy to see that they really did work, but often they did it at and from home, carrying out different activities that were little or no socioeconomically valued, not even by themselves. Likewise, we consider that some women identify themselves as housewives in order to fit into the gender mold, as a survival strategy. Being unnoticed and adjusting to what was expected of them could allow them to get ahead and even receive the family protection aids previously mentioned.

Another factor was a much more restricted conception of work for women, whose activity had to fulfill two conditions to be considered: extra-domestic and salaried. In this way, many productive activities carried out in the domestic and family sphere were made invisible. This is the case of agriculture where farmers and peasant women came to be considered housewives. Spain was eminently rural in the first half of the $20^{\text {th }}$ century, and female employment 
in the primary sector was the general trend. Official figures tended to underrepresent female day laborers, peasants, or farmers in the countryside (García et al. 1995) for two reasons: (1) work in the countryside was subject to great seasonality, with times of high demand for labor combined with others of high unemployment rates and (2) not all women received a wage, working instead for the family unit.

On a nationwide level, there is a range of different agricultures and the role of women differed in each of them. The case of Galicia is quite particular in this sense because it is the region with the lowest "domesticity" ratios, and, along with Asturias, the one with the highest percentage of female smallholders and the one with the highest level of the feminization of family benefits. The notable relative weight of women in agricultural work in Galicia and in northern Spain is related to the importance of small farm holdings, which are key to economic life. The work unit was structured around the family and based, as far as possible, on the collaboration of all its members, without any divisions by gender, and involving a range of different tasks (Díaz-Geada 2015, 150). An excerpt from the preamble of the Decree of November 23 on Rural Qualified Instructors, promulgated in 1953, clearly indicates the significance of their role: "The peasant woman is not only a faithful collaborator for the man, but in many cases she is the material executor of agricultural and livestock tasks, the administrator of the domestic goods of the home, and in all, the selfless depository of the spiritual values of the rural family." ${ }^{\prime \prime}$

Expelled from (or "invited to leave") regulated work, women became actively involved in other economic niches that were not computable from a legallabor perspective, working either informally, such as in family businesses, or illegally. The 1940s were years marked by ration coupons, shortages, a lack of food, and hunger. Supply cards (Fig. 1) were vital for many families, but insufficient. The regime's policy of autarky, which discouraged female involvement in the legal labor market from the pulpit and through its discourse and instruments of socialization, led women playing a lead role in the "black market." The regime's policies launched women onto the roads, railroads and highways, turning them into smugglers who shared, alongside men, the traditional male smuggling routes (Prieto 2018, 97). This is the framework for fraudulent practices in production, transport, marketing, or consumption, that is, in the shadow economy, during the autarky years (Barranquero and Prieto 2003; Soutelo 2006; Román 2015).

In this context, the following youthful memory of Hilda is framed:

19 Official State Journal 333 (November 29, 1953): 7041. 


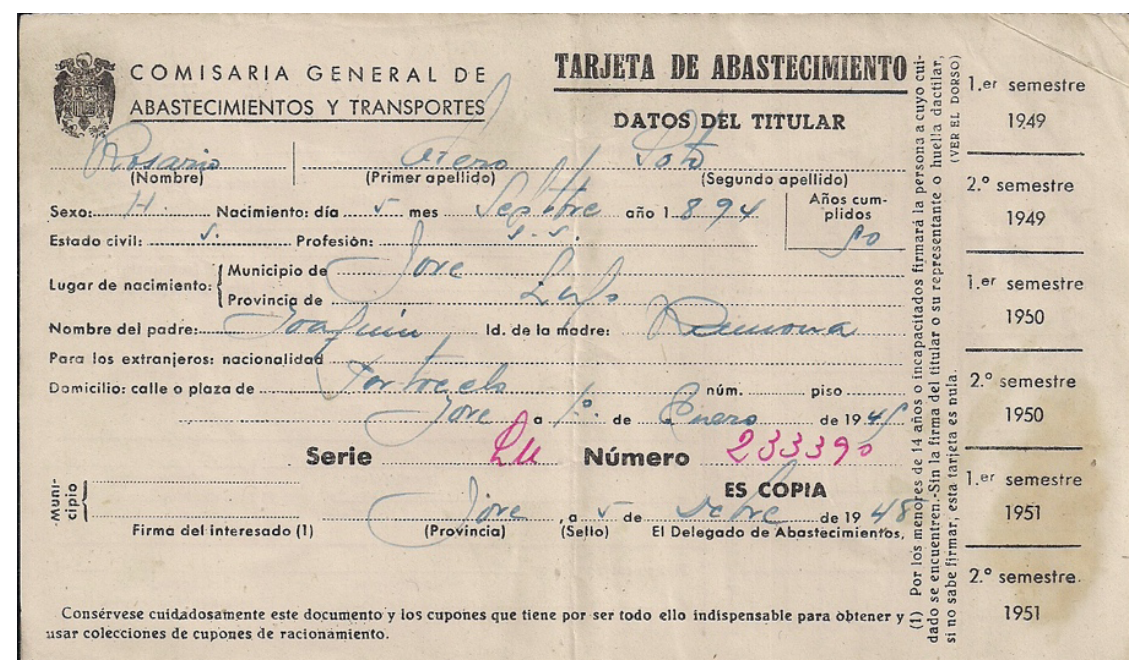

Figure 1: "Supply Card,"Xove (Spain), 1948. ${ }^{21}$

We had to go from Serranillos [del Valle, a town which now forms part of Madrid] to Madrid city for some or other administrative procedure with the supply card. I said to my friend Sarita: 'Well, let's go out dancing, you and me'. What a scandal it will be if they find out! So, we went dancing, 'rat-a-tat-tat-tat'. We had so much fun... But when we got back on the train, she realized she had left her supply card behind. Leaving the supply card back at the dance hall meant a full year of hunger for herself and her mother. She started crying and cried all the way home. I said to her: 'You'll see how ten years from now you don't remember any of this'. I bumped into her recently, and she told me: 'I still remember'. ${ }^{21}$

Hilda's friend suffered the consequences of such adolescent neglect. Sarita's mother - widow of a "red" assassinated by the Francoists - rented rooms for informal accommodation. Hilda stayed there for a while when she moved to this little town where her aunt Guillermina went to teach. Those coupons allowed this single-parent family to survive, and Sarita still remembers how hard it was to lose them. Hunger was everyday fare for many people, especially when there were many mouths to feed. This is the case of the following testimony. Dolores had 13 children, 6 of whom died in childhood, and her husband was sick, so he was unable to work. "I never went hungry

20 From the Author's Family Collection.

21 Hilda Farfante (Boal, 1931). Interviewed by Uxía Otero-González, in O Vicedo, on August 31, 2018; Author's Oral Testimonies Collection, no. 10. 
at my mother's house. However, being married with so many children meant I went hungry. The children never went hungry, huh? I was a slave working for them, but they didn't go hungry." ${ }^{22}$ This woman worked loading sand from the beach into trucks for construction during the day and some nights. She also cooperated in the agricultural and livestock tasks, as well as sold products, such as potatoes or corn, on the "black market." Everything was little to get ahead. She remembers that she lived enslaved by work to feed her family. Turned into heads of families, these women had to manage to subsist through different activities, formal and informal.

Commercial sexual exploitation and the regime's double standards on prostitution are worthy of particular mention: on the one hand, prostitution was tolerated as a "lesser evil" until 1956. On the other hand, a moralization project was implemented to rehabilitate women who, forced by economic and social circumstances, were engaged in prostitution. ${ }^{23}$ Prostitution cannot be separated from the worsening of working conditions or the degradation of living standards due to a significant loss of purchasing power. In the words of the historian Lucía Prieto $(2018,98)$, "Franco's repression not only filled the prisons with women who were committed to or had intentionally assimilated republican and left-wing policies, but furthermore, Spain was also filled with 'whores' and women who were forced into prostitution after being widowed." Alongside the rates of regulated prostitution, reports of clandestine prostitution show increased activity in the most impoverished sectors. However, the Francoist state tried to justify this question through interpretations of public morality, shirking its responsibilities in the prolongation of misery and hunger. Household chores were not recognized as work per se; they were certainly not computable from a labor, mercantile, and monetary perspectives, as they were considered not only an obligation but also a "privilege" that they could enjoy exclusively (Peinado 2012, 100). They were considered to correspond exclusively and inexorably to women, while women's extra-domestic work was perceived as temporary, complementary, and dispensable. Domestic service, which consisted of performing household chores for others, was perhaps the job most specifically occupied by women (De Dios 2016). However, this occupation was not recognized in labor legislation in the first decades of the Franco regime; ${ }^{24}$ it was not worthy of any guidelines or regulations

22 Dolores C. (Arteixo, 1924). Interviewed by Araceli Freire, in Arteixo, on August 20, 2008; Terra e Memoria, HISTORGA (Oral History of Galicia, Spain) Collection, no. 1368.

23 For consideration of prostitution in this period: Roura (2005) and Núnez 2003, among others.

24 It was not until the end of the 1950s that a regulation came into being, via Decree 385/1959 of March 17, 1959, which established the National Domestic Service Mount of Piety. Official State Journal 71 (March 24, 1959): 4578-9. 
and was not even properly remunerated. It was not unusual for women to serve as servants in exchange for food and bed instead of wages. The result was, therefore, that people in domestic service ended up hardly any better off (Sánchez 2009, 65-8). Nevertheless, it provided many young women with a way out of their homes, normally in the countryside, since the tasks involved were those "befitting of their gender" and therefore did not require any special abilities besides those learned from their mothers and in school. In this sense, its transcendence must be recognized at an internal migratory level, from the countryside to the city: these young women were the forerunners of subsequent family emigration, a sort of "placement agency" for their fellow countrywomen, helping them to find work and housing and providing them with contacts for better, faster adaptation to the city (Díaz 2012).

Women were directed toward employment sectors or niches traditionally considered female or more feminine. José Pérez Serrano, Head of the Central Section of Delegations of the Ministry of Labor, was categorical about it: "It goes without saying that there are activities that should be reserved for women, such as those related to needlework, and any work that can be carried out in or near the home, without neglecting related duties. ${ }^{25}$ In this sense, there were women workers in industries such as food processing and textiles because these involved tasks were considered feminine: cooking and sewing (Muñoz 2010; Díaz 2001). In places where male occupation was full, or almost full, and men had a range of employment options, the female workforce was seen as the perfect complement, although not a substitute. The workplace served not only to weave textiles but also helped create networks of solidarity and social bonds, which brought about a sense of community and belonging, leading, in turn, to class awareness, protests about their work situation, and the struggle for their rights (Varo 2007). Although scant attention has been paid to the active, pioneering role of women in working-class conflict, they were nevertheless key as instigators of mobilizations and collective response. An example of this was the boycott of Barcelona's trams due to the increase in ticket prices in the spring of 1951 . Women were so prominent in the conflict that, when writing up a report on the strike, the provincial delegate of Barcelona Trade Unions underlined their recalcitrant attitude in the conflict: "And what is worse, with a large percentage of female workers, almost all of them in the textile industry, who, for reasons of their gender and special way of reacting, cannot be convinced through reasoning or discussion whenever a social conflict arises" (Nash 2010, 158).

25 José Pérez Serrano, El retorno al hogar de la mujer trabajadora [The working woman returns to the home] (Barcelona: Patronato de la Escuela Social de Barcelona, 1945), 19. 
In contrast to the provisions of the 1938 Labor Charter and other laws, the presence of women in workshops and factories was considerable already in the postwar period and even more so after the 1950s and 1960s, as we will see later. ${ }^{26}$ So much so that official school manuals included lessons on the housewife's schedule, and the Francoist State promulgated specific resolutions regarding their timetables. ${ }^{27}$ This question of timetables may seem anecdotal, but as the working women model developed, the "double working day" or "double presence" of women became increasingly consolidated. Working outside the home did not release women from domestic work and the family. Any extra-domestic work was an extra job. Sometimes it is even possible to speak of a "triple working day," when work in the factory and domestic chores were added to the work that was taken home from the factory. This was a modality of particular relevance due to its domestic ubiquity, which functioned as an extension of the factory itself and regulated by its own rules. It was often possible to combine domestic tasks with salaried work because grandmothers or other women, usually family members, looked after the children and did the housework. This invisible division of labor between generations of women deserves recognition. Their contribution was decisive for family survival, making it easier for mothers to continue with the intense work rates (Nash 2010, 147), and it is still the case today.

Female unemployment was not seen as a problem until the desarrollismo (economic development). ${ }^{28}$ The State policies implemented to create employment focused on sectors that had little or no female presence, such as state-funded infrastructures. Nevertheless, there were some exceptions. This is the case of Emilia, who did not embody the normative femininity. She was a single mother, with two children, who smoked and worked among men. She worked on the construction of the stretch of railroad running from Viveiro to Vegadeo, "which was part of the Ferrol del Caudillo to Gijón line, designed to communicate large areas of northwestern Spain":29

26 Sección Femenina de FET-JONS. "Horario para el ama de casa con marido y un hijo." [Timetable for the housewife with husband and child] In Enciclopedia Elemental (Madrid: Altamira, 1957), 666-7.

27 "Resolution of May 10, 1960 of the Directorate-General for Labour Regulation on timetables to be submitted for approval in the textile industries in which women are employed." In La mujer en el trabajo [Women at work] (Madrid: Ministerio de Trabajo, 1973), 71-2.

28 According to official figures from the National Placement Service, female unemployment declined throughout the 1950s and increased in the 1960s because more and more women joined the workforce. Instituto Nacional de Estadística, Anuario estadístico de España. Año 1961 [1961 Statistical yearbook of Spain] (Madrid: Sucesores de Rivadeneyra, 1961), 652.

29 "Ferrocarril Vivero - Vegadeo. Inauguración de un nuevo tramo," [Vivero - Vegadeo Railroad. Opening of a new section]. From the Spanish Film Library, Historical Archive of News and Documentaries (NO-DO) 1331 A (July 8, 1968). http://www.rtve.es/filmoteca/no-do/not-1331/1486819/ [02:20]. 
My mother-in-law was an unusual woman. Her life was particularly difficult. She was a single mother. And working in domestic service for very little money was hardly a solution to her hardship. So she started working alongside men on the railroad tracks. You know, down there. She was just another worker on the site. Don't think that just because she was a woman, she didn't break stones just like the others. ${ }^{30}$

After the parenthesis of the civil war, the "Railroad of the Coast" construction was restarted in the 1940s. However, the mentioned section was not inaugurated until 1968, 75 years after being projected. Emilia did not see it finished, as she died in 1966 at the age of 83, but the memory of her participation in a "men's job" is still alive. Being a single mother placed her on the margins of society. Emilia decided to work as a construction laborer because working as a day laborer in the fields was not enough. Not marrying, or "not marrying well," threw women into the world of work. However, not all women could enjoy the "honor" of embodying the exalted role of the "perfect (house)wife" the Franco regime had entrusted to them. In the difficult context of the period following the civil war, many women, especially those who were heads of families, were forced to work both inside and outside the home to ensure their survival and that of their families. Their salary became the family's only or main sustenance. The female stipend was indispensable, even though it was understood as a mere compliment and relegated to the background through the legal apparatus (Babiano 2007, 25-6). The responsibility of being "breadwinners" fell on them.

In short, women's participation in the labor market was much more relevant than expected for the first decades of Franco dictatorship. Women not only worked but did so in various labor niches, market circuits, and economic sectors. According to official statistics, the female activity rate was below $12 \%$ in $1950 .{ }^{31}$ However, women also took part in other noncomputable activities without any labor recognition, which were outside the narrow conception of work, and outside the official statistics but traceable through other kinds of sources, such as oral testimonies. The women interviewed end up talking about "work, work and more work," but in unequal and precarious conditions due to their legal status as women, with few legal guarantees or protection. In some cases, their activities were hidden because they were carried out within

30 Benedicta González (Cervo, 1922). Interviewed by Uxía Otero-González, in San Cibrao, on August 21, 2013; Author's Oral Testimonies Collection, no. 2.

31 Own estimate based on: Instituto Nacional de Estadística, Censo de la población de España y territorios de su soberania y protectorado, según el empadronamiento realizado el 31 de diciembre de 1950. Tomo $I I I$ [Census of the population of Spain and territories of its sovereignty and protectorate, according to the census conducted on December 31, 1950. Volume III] (Madrid: Sucesores de Rivadeneyra, 1959), 214. 
the framework of the informal economy or directly outside the law. Thus, to what extent did women really embody the ideals of domesticity?

Although official discourse and policies did not support women's extradomestic (and salaried) work, it was admitted in some circumstances. Employment was acceptable for single women, as long as it was transitory in nature; a lesser evil for widows who, having become heads of household, lacked wherewithal; and a disgrace in the case of married women, as it indicated that the husband — whom they were legally and economically subject to- did not earn enough to keep his wife at home (Domingo 2007, 116). Working women were tolerated if they were not married, or, when they had a husband, if he was disabled for work and they suffered economic hardship as their income was below a minimum for the dignity of their families. It was therefore better seen if they were married with children or with children who were now fully grown up, rather than married with small children. These mentalities took root in such a way that still in the 1960s, only $55 \%$ of the housewives surveyed considered that married and childless women should work to help the family; $18 \%$ if they had small children; and 50\% if they did not have children or they were already older. ${ }^{32}$ Women's work was not yet considered a means of personal realization and socioeconomic independence.

In the post-civil war period, women of the popular classes and even the middle classes had to work to ensure their families survival, not only as collaborators in the family economy but also as the only "breadwinners." These women answered in a certain sense the normative femininity because not all women were able, and some did not want, to enjoy the "honor" of playing the role of "perfect married" and "housewives" that the Franco regime had entrusted to them. Consequently, the female active population ratios should not be interpreted as a result of the overwhelming success of the gender discourse and policies, which also changed during the Franco dictatorship.

\section{Pivotal Decade and Economic Takeoff}

Franco's gender discourse and policies were nuanced, reformed, expanded, and transformed throughout Francoism. The metamorphosis of the dictatorship for the sake of its survival had effects that became evident in both labor and gender relations. Over time, the regime adapted its discourse and implemented changes in the legal system based on the context at each

32 FOESSA, Informe sociológico sobre la situación social de España. 1966 [Sociological report on the social situation of Spain] (Madrid: Euramérica, 1966), 63. FOESSA Foundation (Fomento de Estudios Sociales y Sociologia Aplicada) was founded in 1965 with the support of Caritas. It emerged as a charitable organization following the American philanthropic model, to advise economic and political institutions on their social obligations. 
moment. In this regard, we follow the argument set out by Morcillo (2015) in an attempt to underscore the existing tension: first, between the efforts of the Franco regime to control and discipline women (and their bodies) based on a national-Catholic discourse with neo-baroque elements, placing them at the service of the ideals of domesticity; and, secondly, the changes at political, economic, religious, social, and cultural levels, which brought with them distorting elements that collided with the parameters and values in force, threatening and weakening this control.

Francoism had to deal with tensions between its ideal of womanhood and the tendencies resulting from the "modernization process." The "countermodel" cracks become apparent in the mid-1950s, following the international rehabilitation of the Franco regime that began with the Madrid Pact of 1953 and ended in 1955 with the entry into the United Nations. The dictatorship, in an attempt to achieve international recognition, tried to equate the legal situation of women with that of other western countries. Based on Homi Bhabha (2010), Morcillo considers that the 1950s was a "between moments" decade, in which the Franco regime was forced by circumstances to revise its gender discourse and policies, diversifying educational and labor itineraries for women. Due to the demands of the new (inter)national context, the normative femininity was progressively redefined, incorporating new elements but without changing its essence.

Official discourse tried to redirect women toward "female" professions, which apparently did not question the gender model, avoiding competition and female intrusion in traditionally male work activities. The activities highlighted as suitable and fitting of their "nature" were those of mother and caretaker (teacher, midwife, nurse), tasks involving needlework (dressmaker, seamstress), housework at someone else's house (domestic service), and tasks focused on aid, education, and training. In these activities, the women of the FET-JONS Feminine Section and the religious women - both nuns and women of the secular movement- stood out. For example, several professional careers were even set up, such as youth instructors, rural inculcators, social visitors, physical education teachers, etc. (Loring 1992). It is paradoxical that the women of the FET-JONS Feminine Section disowned the discourse they advocated with their modus vivendi, achieving certain self-sufficiency and independence. The Falangist woman's ideal was one thing and the woman's Falangist ideal was another (Barrachina 1991). In short, their logic was "let other women return home" (Morales 2010, 369).

In relation to this paradox, the testimony of Caridad on the loss of femininity due to the increasing involvement of women in the world of work is quite 


\section{Otero-González Gender Labor Policies in the Franco Dictatorship (1939-75)...}

illustrative: "Then the woman was a woman and the man was a man. The woman was a mother and wife, and there was a home in her house. She was not a lawyer in a law firm taking a man's job. ${ }^{{ }^{33}}$ However, curiously, Caridad was involved in training and assistance activities outside the domestic space organized by FET-JONS Feminine Section. She ended up leaving this organization to marry and be the mother of 11 children, embodying herself what she had preached for the others. Anyhow, she never abandoned her active participation in the space beyond the home, presiding over an Association of Housewives in her native Ferrol. ${ }^{34}$

Other professions such as typist (Fig. 2), accountant, clerk, secretary, telephone operator, shop worker, hostess, and concierge also adapted relatively well to the supposed "feminine temperament." These were increasingly common in correlation with the growth of the tertiary sector and the rural exodus from the 1940s onward, and even more so from the 1950s, a pivotal decade for the

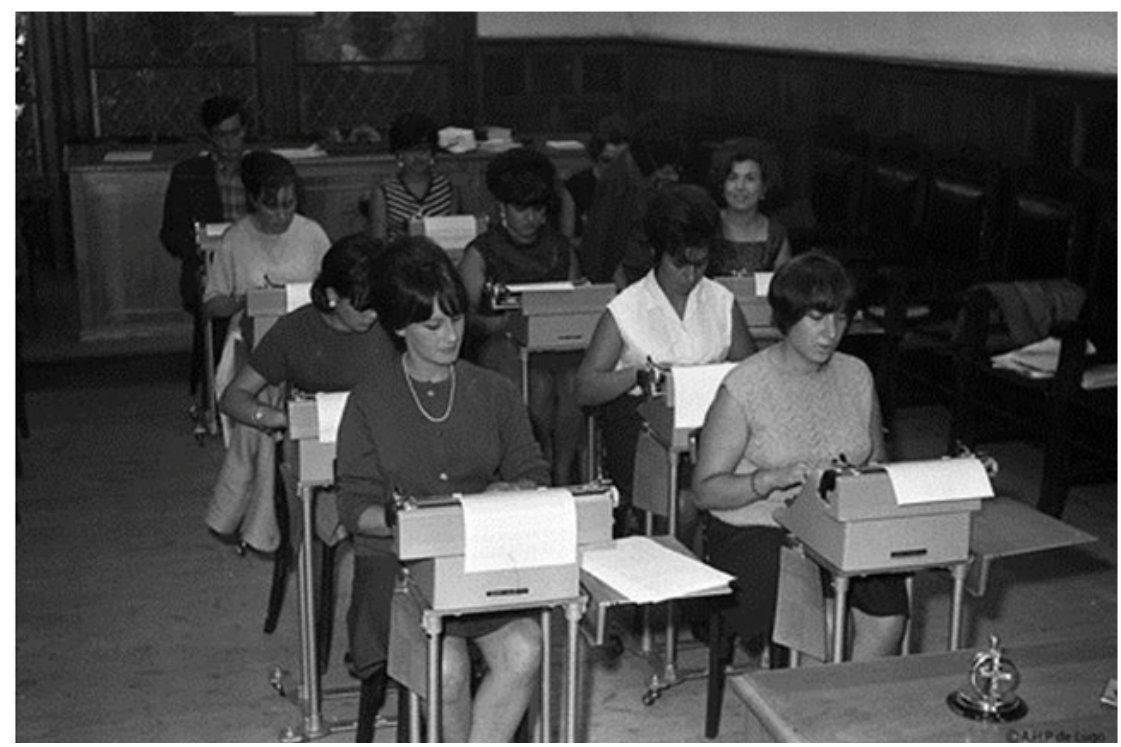

Figure 2: J. L. Vega, "Women in Typing Class," Lugo, 1966. ${ }^{36}$

33 Caridad N. (Ferrol, 1919). Interviewed by Marcelino Fernández, in Ferrol, on March 3, 1989; Terra e Memoria, HISTORGA Collection, no. 45.

34 The associations of housewives that arose in the 1960s contributed to changing this consideration. They became increasingly aware of their subordinate situation and demanded equal political, civil, and social rights from their status as mothers and wives, as the main directors of the family institution. In other words, women found a "legitimate" way (although not the only one) to access their rights without altering the structures of the regime, thus managing to professionalize household tasks (Sáenz 2011).

35 From the Provincial Historical Archive of Lugo (Spain), J. L. Vega Collection, signature 7083-2. 
Franco regime. Without denying the changes that were taking place, school textbooks for girls emphasized the importance of remembering that above all they should be housewives. Above all women had to on their "natural" role as mothers and wives, at home:

Nowadays, as modern trends and circumstances have led young women to work away from home in offices, we are going to refer to women's work outside the home, considering it from the perspective of women and Falange supporters. As women, we find paid work gratifying, as it shows that we are capable of useful, productive work. [...] We feel proud to be useful. However, the confidence which comes from paid work can also be detrimental, making us believe that our place is in the office while overlooking another perfectly feminine role: that of being a housewife. The importance of domestic chores is so great that women should never ignore them or abandon them, not even momentarily. ${ }^{36}$

From the 1950s onward, the socioeconomic situation in Spain began to change, in turn bringing changes in women's education. In 1940, José Pemartín Sanjuán, Head of Secondary and Higher Education at the Ministry of National Education, looked to discredit all "smarty-pants" women looking to continue their education, and advocated a return to traditional values: "Our aim should be to try to channel the large current of female students away from the feminist pedantry of high school and university, where female students should be the exception, and guide them toward their own magnificent feminine being, which is developed in the home. ${ }^{{ }_{37}}$ From the ecclesiastical point of view, the "pernicious consequences" derived from women's studies were also noted, as in the case of the Jesuit pedagogue Enrique Herrera Oria:

Many girls go on to Secondary Education, often with aspirations to continue to university. The reality of the situation is that only a very small percentage end up at university, the rest become minor intellectuals with no training for domestic life. [...] They don't know how to sew a button. Who on earth is going to manage the family in the future? Are men to do the tasks fitting of women? The fatal consequences for the home are clear for all to see. ${ }^{38}$

Although the Francoist state had no interest in promoting female education, there was some progress. This progress was not linear or accelerated but

36 Sección Femenina de FET-JONS, "Curso séptimo. Lección séptima: Trabajo remunerado fuera del hogar. Importancia de las labores domésticas," [Course seven. Lesson seven: Paid work outside the home. The importance of housework.] In Formación familiar y social (Madrid: Delegación Nacional Sección Femenina de FET-JONS, 1969), 222.

37 José Pemartín y Sanjuán, ¿Qué es lo nuevo?: consideraciones sobre el momento español presente [What's new? Considerations of the current Spanish situation] (Madrid: Cultura Española, 1940), 142.

38 Enrique Herrera Oria, Historia de la Educación española desde el Renacimiento [History of Spanish Education since the Renaissance] (Madrid: Veritas, 1941), 438. 
sustained and extending over time. Far from being an obstacle, curricular and institutional segregation consolidated secondary education. ${ }^{39}$ Classist and elitist due to its private religious approach, secondary education was considered an acceptable option for girls from respectable families who could afford to provide their daughters with more extensive education. The study plans were rigidly designed and oriented to college. For many girls from wealthy families, who did not need or did not want to work after finishing high school, universities were the logical continuation, at least until marriage (Canales 2012). The transitory nature of women's higher education was made explicit in textbooks:

From the 1920s on, more or less, this movement began, albeit sporadically, leading to the incorporation of upper-class girls into university studies. [...] But even this intellectual preparation is for the most part a hobby, an ornament without a total practical purpose. [...] I consider that we should only accept this position of the professional training of women with certain reservations, implying that if necessary, women do not deny their collaboration and are qualified to provide it. But if possible, temporarily. With a round trip ticket. Whereas the best thing about a trip is always the return. And the return in this specific case to which we allude is precisely like the return of any trip to the house, to the home. ${ }^{40}$

Transformations were more evident in the 1960s when, within the economic take-off and the Development Plans, the Franco regime introduced certain legal modifications that allowed women to access all levels of education and join the working population en masse. The point of no return was marked by Act 56/1961, of July 22, on women's labor and professional political rights, ${ }^{41}$ although this did not bring an essential modification of the Francoist archetype of women. Let us simply consider the words of Pilar Primo de Rivera, National Delegate of the FET-JONS Feminine Section, in the Spanish Parliament in defense of the law in question: "In no way do we want to make man and woman two equal beings; neither by their nature nor by the ends to be fulfilled in life can they ever be equal, but we do ask that in equal of functions, equal rights. ${ }^{32}$ The implementation of this law and the increase in the acceptance of feminine work by society were phenomena that seem

39 Official State Journal 58 (February 27, 1953): 1119-30.

40 Carmen Werner, "Lección XX. La mujer y las profesiones," [Lesson XX. Women and professions.] In Convivencia social. Formación familiar y social. Tercer curso de bachillerato (Madrid: Sección Femenina FET-JONS, 1958), 160-1.

41 Official State Journal 175 (July 24, 1961): 11004-5.

42 Sección Femenina de FET-JONS, Derechos Politicos, Profesionales y de Trabajo de La Mujer [Women's Political, Professional and Labor Rights] (Madrid: Delegación Nacional Sección Femenina de FET-JONS, 1971), 31-3. 
to have appeared together in time, without clarifying which is previous and causing the other. This legal initiative gave de jure legal backing to economic, social, and other transformations that the country had already experienced de facto. The pressing integration of women into the workforce made it essential to update the regulations in this regard.

However, this norm is explained by a gradual acceptance of the transformations, an adaptation to the changing mentality of the population, and, above all, an adaptation to the international rehabilitation in the post-1945 panorama. It was not so much a simple change of mentality in the elite. Nor was it the result of the demands of the population, because the regime had no interest in translating their wishes into policies. Nor was it a necessary complement to the economic policy initiated with the Stabilization Plan of 1959 because, among other issues, the 1961 Law prohibited all labor discrimination and legislation that protected discriminatory practices would have been more economically profitable. This was a pragmatic adaptation to new times marked by US dollars in exchange for military bases geostrategically placed on the Iberian Peninsula in the framework of the Cold War (Morcillo 2018, 173-5). At the same time, this was a clever propaganda procedure of convenience for the FET-JONS Feminine Section - that in any case failed to paralyze the growing disaffection of the women toward the Falangist organization(Ruiz 2016).

This law also had an educational dimension. Art. 3.1 further stated that "[women] shall have access to all levels of education," an implicit recognition that it was not so ostensible before. In this regard, the White Paper published by the Ministry acknowledged that there were certain "[...] attitudes rooted in Spanish society (some of which are fortunately disappearing) that hinder the cultural and professional advancement of women." ${ }^{33}$ Despite these attitudes, the percentage of women was in crescendo in all stages, especially at university, where they were a minority for the most time. Metaphorically speaking, women did not enter through the front door, but rather through the side door and even the windows (Saavedra 2016, 506-7). Although women could access the university system, they did so by facing sociocultural conventions and not infrequently what was expected of them. Already in the 1940s, the pages of $Y$ included the most acceptable careers for women:

A woman's real career is that of mother of a family. [...] However, [...] some women need their work to make a living. In these cases, we provide our readers with useful information on the different

43 Ministerio de Educación Nacional, La educación en España: bases para una politica educativa [Education in Spain: bases for an education policy] (Madrid: Ministerio de Educación Nacional, 1969), 122. 


\section{Otero-González \\ Gender Labor Policies in the Franco Dictatorship (1939-75)...}

professions that can be exercised by women in accordance with their vocation. [...] Intelligent women who are fond of studying can choose to create a future for themselves through a university degree based on their preferences. The most suitable courses for women are Philosophy and Letters, and Pharmacy, although there is freedom of choice as all degrees are open to women. ${ }^{44}$

In the 1950s, these were the university careers with the highest number of women, albeit this trend was already present even before the victory of the Francoists. In the academic year 1939-40, women represented almost 50\% of enrollments in the Faculty of Pharmacy of the University of Santiago de Compostela. ${ }^{45}$ In general, the careers seen as involving an extension of their role as mother or wife, or derivatives of them, had more women in their classrooms. It is therefore no surprise that they are present in Medicine, specializing in particular in areas related to women (Gynecology) and children (Pediatrics). These "preferences" were maintained until the popularization of university studies in the 1960s. Thus, the increase in female enrollment in Law School, traditionally male, was very notable. According to FOESSA reports, the figure rose from $2.8 \%$ in the second half of the 1940 s to $12 \%$ for the academic year 1963-4. ${ }^{46}$ These university women had the opportunity to learn about the legal system and its foundations. This was how they could begin to question it, leading to the first struggles for change to overcome inertia.

More and more people were studying and working in the 1960s. Women made up $18 \%$ of the working population in 1960 , and by 1964 , this figure stood at $24 \%$; $^{47}$ a continued increase was also foreseen in the $1^{\text {st }}$ Economic and Social Development Plan (1964-67). ${ }^{48}$ The figures referring to the total number of women in employment increased remarkably, although they were still very low compared to other countries. Moreover, official figures tended to underestimate the actual number of working women due to the trend for them to declare that they were devoted to domestic work. Professional groups such as those in health, education, public administration, commerce, and the food and drink industry (under the guise of tourism development) already recorded a significant percentage of women over these decades.

44 “Carreras para la mujer." [Careers for women.] Y 44 (1941): 18-9.

45 Libro de registros de matrícula del curso 1939-1940, Arquivo Histórico da Universidade de Santiago de Compostela, Fondo Universitario, Matrículas, Signatura F. U., A-2462.

46 FOESSA, Informe sociológico sobre la situación social de España. 1966 [Sociological report on the social situation of Spain. 1966] (Madrid: Euramérica, 1966), 162-3.

47 Ibid., 62.

48 Official State Journal 312 (December 30, 1963): 18190-8. 
In the 1960s, not only did changes take place on the educational level but also an acceleration of political, economic, and sociocultural transformations. The restructuring of European capitalism after World War II meant that the Spanish migratory flow toward Latin America dried up and headed toward this new continental labor market in the late 1950s and 1960s (Babiano and Farré 2002). At the sociocultural level, roundtrip migration processes played a crucial role in spreading new patterns of behavior and consumption, as well as further consolidating the model of working women. Furthermore, many women replaced the men who had left their jobs by emigrating to other European countries, such as France and Switzerland. In this decade, there were changes in the religious sphere and the Catholic discourse, supposedly monolithic, became more visible and public. The new religious (and political) culture derived from the Vatican Council II (1962-65) came into contradiction with the immobility of the Franco regime and the Spanish ecclesiastical hierarchy. While their discourse on "women" had clear limitations, the most dynamic sectors of the clergy and laity formed a Catholic counter-discourse and a new identity for Catholic women. The main Catholic women's organizations such as the Catholic Workers Youth (JOC) — contributed to redefining the Catholic femininity and conceptualized women as professionals or workers, with an identity less related to motherhood and domesticity. This led them to a reinterpretation of the women's apostolate and of gender relations within the Church (Moreno 2008).

The 1970s began with the promulgation of the General Education Law, in which the mandatory separation of boys and girls is not mentioned for the first time in Franco's legislation. ${ }^{49}$ It was also enacted then the Decree 2310/1970, of August 20, regulating the labor rights of working women, ${ }^{50}$ which arose due to the limited applicability of Decree 258/1962 of February $1,{ }^{51}$ which had failed to provide equality of labor rights for men and women. Its preamble read as follows:

The growing participation of women in labor activities is of extraordinary importance in the current stage of economic and social development, while the evolution of many of the concepts that inspired the specific legislation on women's work is evident, to the point that female equality is increasingly necessary, and universally accepted,

49 Official State Journal 187 (August 6, 1970): 12525-46.

50 Official State Journal 202 (August 24, 1970): 13756.

51 Decree 258/1962 of February 1, applied to the sphere of employment Act 56/1961 of July 22, which equates workers of either gender in their employment rights. Official State Journal 41 (February 16, 1962): 2345-6. 
both in order to find employment and also to work in equal conditions as male workers. ${ }^{52}$

The last regulation decreed by Franco's government was Act 14/1975 of May 2, 1975, on the legal status of married women and the rights and duties of spouses, which emphasized the need to adapt the body of law to the times: "One of the currents of opinion most strongly felt today [...] is the one that affects the legal status of married women. This suffers from significant limitations in its ability to act, with the initial reasons behind it now being lost." ${ }^{33}$

Although the above-mentioned policy changes may suggest that Spain was moving toward increased gender equity, the currents of opinion still accepted that domestic work was the domain of women in 1975 (Romo 2017, 229). In this sense, $70.1 \%$ of men and $66.3 \%$ of women interviewed for the FOESSA report thought that women's education "should be more oriented toward caring for a family rather than learning a profession." Moreover, both genders practically agreed that "the wife should be at home when the husband returns from work" (78.6\% of men and $79.3 \%$ of women) and that "the wife should not have any activities outside the home without the husband's permission" (70.1\% of men and $66.3 \%$ of women). It was commonly accepted that only in the event of the wife's illness should the husband be responsible for domestic chores. $^{54}$

The legal reforms were not designed to discard the "natural" role of women but ended up reinforcing the discourse on domestic responsibility as their primary task. Although the discursive and legal framework in 1975 was quite different from that of the immediate post-civil war period, women continued to be relegated to the domestic space. However, there was a difference. With the transition to a consumer society beginning in the 1950 s, it became the increasingly common purchase of durable consumer goods, such as refrigerators, washing machines, and other household appliances (Fig. 3)..$^{55}$ Housewives, who became then (re)producers and consumers, saw their tasks become increasingly automated and household appliances completely transformed domestic work, reducing the time required to complete them and facilitating the combination of work at home with their unstoppable incorporation into employment. Thus, women also added masculine roles

52 Ministerio de Trabajo, La mujer en el trabajo [The woman at work] (Madrid: Ministerio de Trabajo, 1973), 95.

53 Official State Journal 107 (May 5, 1975): 9413.

54 FOESSA, Informe sociológico sobre la situación social de España. 1975 [Sociological report on the social situation of Spain. 1975] (Madrid: Euramérica, 1976), 378.

55 Ibid., 982. 


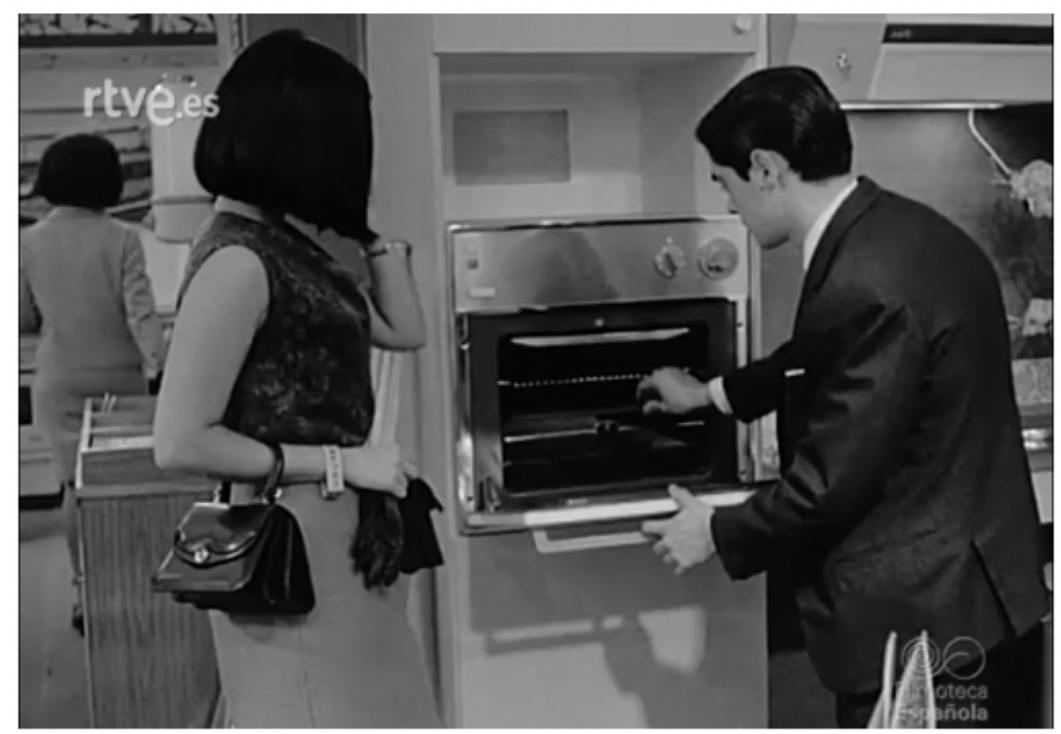

Figure 3: "Latest News in Household Appliances in The Monographic Room 'Hogarotel 6," Barcelona, $1966 .{ }^{57}$

and functions so far, as well as academic and professional horizons to this invariance, providing irrefutable proof of gradual adaptation to different circumstances and helping to end the "forced enclosure in a 'small world" (Molinero 1998).

\section{Final thoughts}

The normative femininity is built not only through social and legal norms but also through political, moral-religious, medical-scientific, literary discourses, in relation to and contrast with masculinity. These gender models condition the possibilities of life, experiences, women's expectations, and their own selfperception. These archetypes are complex, often contradictory, full of tension and fissures, and in any case open to interpretation (Bolufer 2018, 77-135). This research aims to analyze how the Franco dictatorship "consented" to a certain extent to realities that a priori did not "fit well" with its discourse. The gap between restrictive legislation or the imposition of a rigid model of womanhood and a socioeconomic reality that overflowed the narrow limits of

56 From the Spanish Film Library, Historical Archive of News and Documentaries (NO-DO) $1246 \mathrm{~B}$ (November 21, 1966). http://www.rtve.es/filmoteca/no-do/not-1246/1486798/ [00:46] 
normative femininity is a way for historiographical innovation on the Franco dictatorship.

The gender labor policies of the Franco dictatorship urged women to focus on the domestic-reproductive sphere. However, socioeconomic reality surpassed the limits set by Francoist discourse and legislation. The dichotomous division of spaces did not become fully effective. Many women studied beyond primary school and entered the workforce. Women overstepped the bounds of the official gender model according to their capacities, needs, social circumstances, and economic possibilities. Women crossed the thresholds of domestic space and even brought additional domestic tasks from the factory to the house. Most of them were working-class women who had no choice but to try to alleviate the precarious situation that their families suffered, thus reconciling their role as mothers and wives with the contribution to the economic maintenance of the family nucleus. Carmen expresses this idea in a simple way:

Some women had to go out to make a living if they didn't want to starve [...]. They had to make a living somehow. Quite simply, if there was no income, people had to look for a way to make ends meet, and there were many cases in which working men had died in the war, leaving behind a wife and children, while others had to go out to work no matter what in order to raise their children. ${ }^{57}$

Carmen speaks in the third-person plural because it was not her case. She recognizes that other women's circumstances were more complicated than hers because she married an army officer of the winning side who was placed in the police force at the end of the civil war. She only decided to go to work later to contribute financially so that her son could study at university. Carmen took advantage of the fact that a neighbor sold his butcher shop and bought it, becoming a butcher. Obviously, not everyone could acquire the transfer of a business, but she had certain financial stability to start and try to give her son a better future. Women of the upper-middle classes also went to work but with less financial need. They had status and socioeconomic possibilities, some academic training, and even the help of other women who took on the domestic chores, all of which allowed them to have employment aspirations, and, to a certain degree, to challenge the normative femininity. Consequently, not all women (far from it) embodied normative femininity because some did not want to and others could not.

57 Carmen D. (A Coruña, 1917). Interviewed by M. ${ }^{a}$ Isabel Acero, in A Coruña, on January 20, 1990; Terra e Memoria, HISTORGA Collection, no. 187. 
The presence of women in the workplace was therefore consolidated based on discriminatory criteria. Women were present in all of the above activities and in many others besides, although occupational gender segregation is clear. Women and men were distributed differently in the structure of the labor market. First, carrying out different occupations (horizontal segregation); not so much by free choice, but rather choice conditioned by their education and working conditions, that is, the possibility of combining work and family. Second, occupying the lowest levels of the labor hierarchy (vertical segregation), which had a direct impact on both wage policies and on the opportunities for training, qualification, and promotion (Borderías 2007, 9-37).

Nevertheless, labor policies and official discourses are not solely responsible for the gender relations found in the labor market. Women were concentrated in the least productive, competitive, and qualified, as well as worst-paid sectors. Women suffered much more the effects of unemployment. Women were concentrated in informal, submerged, irregular, and seasonal employment such as the food industry. However, these circumstances were not exclusive to the Franco regime. The division of labor between women and men, the existence of (un)suitable occupations for both, and, above all, the fact that women had to bear the burden of domestic work and family care - at a time when public services such as nurseries, canteens or residences were almost non-existent, and very few families could afford to pay for private onesare traditional aspects in the market economy, in which gender division is a fundamental pillar, transcending the historical context analyzed.

\section{References}

Arbaiza, Mercedes. 2000. "La 'cuestión social' como cuestión de género. Feminidad y trabajo en España (1860-1930).” [The 'social question' as a gender issue. Femininity and work in Spain (1860-1930)] Historia Contemporánea (21): 395-458.

Babiano, José. 2007. "Mujeres, trabajo y militancia laboral bajo el franquismo (materiales para un análisis histórico)." [Women, work and labor militancy under the Franco regime (materials for historical analysis)]. In Del hogar a la huelga: trabajo, género y movimiento obrero durante el franquismo, 25-76. Madrid: Catarata.

Babiano, José, y Sebastián Farré. 2002. "La emigración española a Europa durante los años sesenta: Francia y Suiza como países de acogida." [Spanish emigration to Europe during the 1960s: France and Switzerland as host countries.] Historia Social 42: 81-98.

Barrachina, Marie-Aline. 1991. "Ideal de la mujer falangista. Ideal falangista de la mujer." [Falangist woman's ideal. Falangist ideal of women]. In Las mujeres y la guerra civil española, 211-17. Madrid: Ministerio de Asuntos Sociales - Ministerio de Cultura. 


\section{Otero-González \\ Gender Labor Policies in the Franco Dictatorship (1939-75)...}

Barranquero, Encarnación, and Lucía Prieto. 2003. Asi sobrevivimos al hambre: estrategias de supervivencia de las mujeres en la posguerra española. [That's how we survived hunger: female survival strategies in the Spanish post-civil war period]. Málaga: Diputación de Málaga.

Bhabha, Homi. 2010. The Location of Culture. London: Routledge.

Bolufer, Mónica. 2018. Mujeres y hombres en la Historia. Una propuesta historiográfica y docente. [Women and men in history. A historiographic and teaching proposal.] Granada: Comares.

Borderías, Cristina. 2007. Género y politicas de trabajo en la España contemporánea, 18361936. [Gender and labor policies in contemporary Spain, 1836-1936]. Barcelona: Icaria - Universitat de Barcelona.

Canales, Antonio F. 2012. "Little intellectuals. Girls' academic secondary education under Francoism: Projects, realities and paradoxes," Gender and Education 24 (4): 375-91.

De Dios, Eider. 2016. "Sirvienta, empleada, trabajadora de hogar. Género, clase e identidad a través del servicio doméstico en el Gran Bilbao (1939-1985).” [Servant, employee, domestic worker. Gender, class and identity through domestic service in Greater Bilbao (1939-1985)]. PhD diss., Universidad del País Vasco.

Díaz-Geada, Alba. 2015. "Modernizar en femenino. Algunas notas sobre el trabajo de las agentes de economía doméstica y los cambios socioeconómicos y culturales en el rural gallego del tardofranquismo." [Modernize in feminine. Some notes on the work of domestic economy agents and socioeconomic and cultural changes in rural Galicia during the late Franco regime]. Historia Actual Online (36): 149-61.

Díaz, Pilar. 2001. El trabajo de las mujeres en el textil madrileño: racionalización industrial y experiencias de género (1959-1986). [The work of women in the Madrid textile industry: industrial rationalization and gender experiences (1959-1986)]. Málaga: Universidad de Málaga.

__— 2012. "El trabajo de las mujeres españolas en el siglo XX: permanencia y cambio." [The work of Spanish women in the 20th century: permanence and change]. In Trabajo, creación y mentalidades de las mujeres: una visión interdisciplinar, 15-36. Valladolid: Universidad de Valladolid.

Domingo, Carmen. 2007. Coser y cantar: Las mujeres bajo la dictadura franquista [Sewing and singing: Women under the Franco dictatorship]. Barcelona: Lumen.

Escribano, Juan. 2009. "La mujer trabajadora en el franquismo: Análisis jurídico-laboral." [Working women during Francoism: Legal-labor analysis]. In Derecho, Memoria Histórica y Dictaduras, edited by Federico Fernández-Crehuet López and Daniel J. García López, 199-238. Granada: Comares.

Espigado, M.a Gloria. 2018. “'El ángel del hogar’: uso y abuso historiográfico de un arquetipo de feminidad." ["The angel of the home": historiographic use and abuse of an archetype of femininity] In Feminidades y masculinidades en la historiografía de género, edited by Henar Gallego, 195-212. Granada: Comares.

Espuny, M.a Jesús. 2006. "Aproximación histórica al principio de igualdad de género (I): Propósitos y realidades en la II República española." [Historical approach to the principle of gender equality (I): Purposes and realities in the Second Spanish Republic]. IUSLabor (3): $1-6$. 
2007a. "Aproximación histórica al principio de igualdad de género (II): el empleo femenino después de la guerra." [Historical approach to the principle of gender equality (II): Women's employment after the war]. IUSLabor (1): 1-7.

2007b. "Aproximación histórica al principio de igualdad de género (III): las Reglamentaciones de Trabajo, observatorios de la desigualdad." [Historical approach to the principle of gender equality (III): Labor Regulations, observatories of inequality]. IUSLabor (2) (2007): 1-8.

García, M. ${ }^{a}$ Dolores, et al. 1995. Mujer y agricultura en España: Género, trabajo y contexto regional. [Women and agriculture in Spain: Gender, work and regional context]. Barcelona: Oikos-Tau.

Gómez de Aranda y Serrano, Luis. 1970. "La excedencia y la dote laboral de la mujer trabajadora." [The woman's leave of absence and dowry worker]. Revista de Politica Social (86): 5-65.

Iglesias, M. a Antonia. 2007. Maestros de la República: los otros santos, los otros mártires. [Teachers of the Republic: the other saints, the other martyrs]. Madrid: Esfera de los Libros.

Llona, Miren. 2012. "Historia oral: la exploración de las identidades a través de las historias de vida." [Oral history: the exploration of identities through life stories] In Entreverse: teoria y metodología práctica de las fuentes orales, 15-60. Bilbao: Universidad del País Vasco/Euskal Herriko Unibertsitatea.

Loring, Teresa. 1992. "Promoción político-social de la mujer durante los años del mandato de Francisco Franco." [Political-social promotion of women during Francisco Franco's office]. In El legado de Franco, edited by Fundación Nacional Francisco Franco, 585-636. Madrid: Azor.

Molinero, Carme. 1998. "Mujer, franquismo, fascismo: La clausura forzada en un 'mundo pequeño'” [Women, Francoism, Fascism: Forced enclosure in a 'small world']. Historia Social (30): 97-117.

Morales, Amalia. 2010. “Género, mujer, trabajo social y Sección Femenina: Historia una profesión feminizada y con vocación feminista." [Gender, women, social work and the FETJONS Feminine Section: History of a feminized profession with a feminist vocation]. PhD diss., Universidad de Granada.

Morcillo, Aurora. 2000. True Catholic Womanhood: Gender Ideology in Franco's Spain. Illinois: Northern Illinois University.

2010. The Seduction of Modern Spain. The Female Body and the Francoist Body Politic, Lewisburg: Bucknell University.

2015. En cuerpo y alma. Ser mujer en tiempos de Franco. [In body and soul. Being a woman in Franco's time]. Madrid: Siglo XXI.

_—_. 2018. "Gender." In The History of Modern Spain. Chronologies, Themes, Individuals, edited by José Álvarez and Adrian Shubert, 165-79. London: Bloomsbury.

Moreno, Mónica. 2008. "Ideal femenino y protagonismo de las mujeres en las culturas políticas del franquismo." [The feminine ideal and the role of women in the political cultures of Francoism.] Arenal 15 (2): 269-93. 


\section{Otero-González \\ Gender Labor Policies in the Franco Dictatorship (1939-75)...}

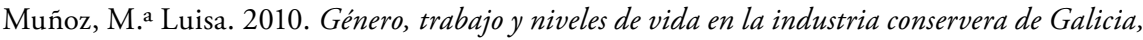
1870-1970. [Gender, work and living standards in the Galicia food preservation industry, 1870-1970]. Barcelona: Icaria.

Nash, Mary. 2010. “Sin derechos: trabajadoras bajo el franquismo (1939-1975).” [No rights: Workers under Franco (1939-1975)]. In Trabajadoras: un siglo de trabajo femenino en Caluña (1900-2000), 127-64. Barcelona: Generalitat de Catalunya.

Núñez, Mirta. 2003. Mujeres caídas: prostitutas legales y clandestinas en el franquismo. [Fallen women: legal and clandestine prostitutes in Francoist Spain]. Madrid: Oberon.

Peinado, Matilde. 2012. Enseñando a señoritas y sirvientas: formación femenina y clasismo en el franquismo. [Teaching ladies and servants: women's training and class discrimination in Francoist Spain]. Madrid: Catarata.

Prieto, Lucía. 2018. Mujer, moral y franquismo. Del velo al bikini. [Women, morality and Francoism. From the veil to the bikini]. Málaga: Universidad de Málaga.

Román, Gloria. 2015. Delinquir o morir: El pequeño estraperlo en la Granada de posguerra. [Crime or death: small-scale black marketing in post-war Granada]. Granada: Comares.

Romo, Carmen. 2017. El extraño viaje del progreso: Discursos sobre la cotidianidad e identidades femeninas durante el desarrollismo franquista [The strange journey of progress: Discourses on everyday life and feminine identities during Francoist developmentism]. Sevilla: Athenaica.

Roura, Assumpta. 2005. Un inmenso prostibulo: Mujer y moralidad durante el franquismo [An immense brothel: Woman and morality during the Franco regime]. Barcelona: Base.

Ruiz, M. a del Rosario. 2016. "El canto de cisne de la Sección Femenina de FET y de las JONS." [The swan song of the FET-JONS Feminine Section.] Ayer 102 (2): 121-43.

Sáenz, Aritza. 2011. "Las amas de casa. Sujeto constructor de derechos durante el franquismo." [Housewives. Rights builders during the Franco regime]. Arenal. Revista de Historia de Las Mujeres 18 (1): 181-216.

Sarasúa, Carmen, and Carme Molinero. 2009. "Trabajo y niveles de vida en el franquismo. Un estado de la cuestión desde una perspectiva de género." [Work and living standards in Francoist Spain. A state of the question from a gender perspective]. In La historia de las mujeres: perspectivas actuales, edited by Cristina Borderías, 309-54. Barcelona: Icaria.

Soutelo, Raúl. 2006. Labregas, emigradas, estraperlistas e represaliadas: experiencias de vida e lembranzas de mulleres na Galicia rural, 1900-1960. [Female farm workers, emigrants, black marketeers and victims of retaliation: Life experiences and memories of women in rural Galicia, 1900-1960]. Valga: Concello de Valga.

Valiente, Celia. 1997. "Protección y prohibición. Los regímenes autoritarios: las dictaduras de Mussolini (1922-1943), Primo de Rivera (1923-1930) y Franco (1936-1975).” [Protection and prohibition. Authoritarian regimes: the dictatorships of Mussolini (1922-1943), Primo de Rivera (1923-1930) and Franco (1936-1975)] In Politicas públicas de género en perspectiva comparada: la mujer trabajadora en Italia y España, 59-98. Madrid: Universidad Autónoma de Madrid.

Varo, Nàdia. 2007. “Mujeres en huelga.” In Del hogar a la huelga: trabajo, género y movimiento obrero durante el franquismo, [From the home to being on strike: Work, gender and labor movement during the Franco regime], edited by José Babiano, 189-244. Madrid: Catarata. 